\title{
Analysis of the Right to Education in Indian Constitution
}

\author{
Dr. S. Kumar Swami* \\ Reader in Pol.Sc. Kamala Nehru Women's College, Unit-1, Bhubaneswar
}

*Corresponding Author: Dr. S. Kumar Swami, Reader in Political Science, Kamala Nehru Women's College, Bhubaneswar

\begin{abstract}
As per United Nations Universal declaration of Human rights-everyone has the right to Education. Education shall be free, at least in the elementary and fundamental stages. The Indian constitution is known to be a document committed to social justice. The constitution has recognized education as the essence of social transformation. The Right of children to free and compulsory education Act came into force from April,1 2010. The detail elaboration of the right and its amendments are explained in this paper. The Right to Education clarifies that compulsory education means obligation of the Govt. to provide free elementary education. Free means that no child shall be liable to pay any kind of fee or charges. The detail provisions of right to education act are explained in this article. The children are getting benefits through rights. Through education the child develops his emotional, intellectual and spiritual growth. Otherwise there cannot be a healthy growth of the nation. This paper explains the necessity of education which empowers the future generation and it should always be the main concern of any nation.
\end{abstract}

Keywords: United nations Universal declaration of Human rights, Right to education in India, its constitutional perspective, Right to education act, the provision of RTE Act and the benefits of the act.

\section{INTRODUCTION}

Everyone has the right to education. Education shall be free, at least in the elementary and fundamental stages. Elementary education shall be compulsory (Article 26 of 1948 Universal Declaration of Human Rights). This UN recommendation has been reinforced in the provision of the right of children to free and compulsory education (RTE) Act. 2009. The Indian constitution in its original enactment made some provisions which are having a great bearing on the functioning of educational system in India. The constitution makes the following provisions which are the follows:

\section{Article 28}

This article provides freedom as to attendance at religions worship in educational institutions.

\section{Article 29}

It says equality of opportunity in educational institutions.

\section{Article 30}

It accepts the right of the minorities to establish and administer educational institutions.

\section{Article 45}

According to this article "state shall endeavour to provide within a period of ten years from the commencement of this constitution for free and compulsory education for all children until they complete the age of 14 years."

\section{Article 46}

It provides for special care to the promotion of education and economic interests of the SC, ST and other weaker sections of society.

\section{Article 337}

This provides for special provision with respect to educational grants for the benefit of Anglo-Indian community. 


\section{Article 350 A}

This article relates to facilities for instruction in mother tongue at primary stage.

Article 350 B

It provides for a special offer for linguistic minorities.

\section{Article 351}

This article relates to the development and promotion of the Hindi language.

The seventh schedule of the Indian Constitution contains legislative powers under three list viz: The union list, the state list and the concurrent list,

The Union List: This list containing 99 subjects where the following entries are related to education.

Entry 13: It provides educational and cultural relations with foreign countries.

Entry 62: The institutions are known at the commencement of the constitution as National library. The Indian Museum, the victorial memorial and Indian war memorial etc. to be declared by law to be an institution of national importance.

Entry 63: The commencement of this constitution as the BHU, AMU and Delhi University etc. declared by parliament by law to be an institution of national importance.

Entry 64: The institution of scientific and technical education declared by law to be institutions of national importance like IITs and IIMs.

Entry 65: Union agencies and institutions for I) Professional, Vocational or technical training including the training of police officers. II) The promotion of special studies of research. III) Scientific or technical assistance in the investigation of detection of crime.

Entry 66: Co-ordination and determination of standards in the institution of Higher education or research and scientific and technical institutions.

State list: State list consists of 62 entries out if which the following is the entry related to education.

Entry 12: According to this entry all libraries, museums and other similar institutions controlled or financed by the state.

Concurrent list: It comprises 52 entries among them following are related to education.

Entry 20: There are some economic and social plannings for education.

Entry 25: Education including technical education, medical education and universities subject to provision of entries 63,64,65,66 of list (union list).

Entry 34: Newspaper, books and printing presses.

Apart of these articles and the different items in the above three lists, there are also some reservations in education in India.

Nearly eight years after the constitutions was amended to make education a fundamental right, the government of India from $1^{\text {st }}$ April 2010 implemented the law to provide free and compulsory education to all children in age group of 6-14 years.

\section{PROVISIONS OF THE ACT PROVIDING MANY FACILITIES}

The $86^{\text {th }}$ amendment of the constitution in Dec. 2002 and its enactment since $1^{\text {st }}$ April 2010 has made free and compulsory education for all children 6-14 age groups a justifiable fundamental right.

The Act makes it a right of every child to get education. The Act makes it obligatory for the government to ensure that every child gets free elementary education.

That Act mandates that even private educational institutions have to reserve 25 percent seats for children from weaker sections.

The Act says no school can deny admission to a student and all schools need to have trained teachers. In case of schools not having trained teachers, they will have to comply with the provision within three years. 
As per the law, the schools need to have certain minimum facilities like adequate teachers, playground and infrastructure.

The government has already prepared model rules which have been circulated to the states for preparing their own rules for implementation of the Act.

The state Government and local authorities will establish primary schools within walking distance of one $\mathrm{Km}$ of the neighborhood. In case of children for class VI to VIII, the school should be within a walking distance of three $\mathrm{Km}$ of the neighborhood.

But there is a mixed response from all those who have been aspirants of this act. Government does not have sufficient resources for the spread of education. Again there is no reliable statistics regarding out of school children in India, who have been excluded from the mainstream education for decades. The RTE Act does not include its regulatory mechanism to private un-aided schools. Now government is keen to open "Model Schools" rather than introducing "Common school system and hence promoting a multi layered education system to device rich and poor children. The Act covers children between 6 and 14 and does not cover above 14 till 18 and below 6 years.

Further the Indian child labour Act on child labour draw line between hazardous and non hazardous child labour and non hazardous child labour is allowed below 14 years. Necessary amendment need to be made to declare that all forms of child labour is hazardous and should be banned.

The RTE Act covers children between 6 and 14 years whereas the article 45 of this, constitution envisaged all children below 14 years to be covered within 10 years to come under free and compulsory education. Also it is an contradiction to the definition of children as per international covenants (CRC 1990).

\section{SUgGeSTIONS}

The above discussion brings that it is a great responsibility for government to shoulder if the promises of the acts to be kept. Some suggestions in this regard have been put forward.

- It should be made mandatory in real terms to make all the deaths, births and marriages registered and monitored by the state. Unfortunately not all the births and deaths are registered in our country. The registrar general of India may be directed to ensure inclusions of all the births, death and migration as well as marriages registered for monitoring their well beings and school enrolment.

- 6 percent of GDP or 20 percent of government expenditure should be provisioned for education and half of this public spending on education needs to be targeted towards elementary education.

- To ensure quality of education, regular and trained teacher should be recruited in place of untrained and para teachers. Para teachers recruited so far should be trained and regularized.

- The existing laws for protection of child rights should be enforced suitably and implemented strictly for total eradication of the menaces of child labour, child servitude and child trafficking and all the children of age group 0-18 years are enrolled in schools.

- Provisions should be made in the said legislation for quality education system with measurable indicator so that parents and community can monitor the quality of education.

- All efforts should be geared to ensure the common schooling system for all the children irrespective of their parent's socio-economic status.

- All forms of privatizations including the public private partnership or franchise to corporate bodies that leads to profiteering, commoditization and weakening the public education system should be dropped.

- The awareness through civil society, youth and NGOs has to be made for the weaker section to avail the rights and to accept them as a part of our society. All of us have to accept them with open heart to study our kids' disregard of the fact of their socio economic background.

\section{CONCLUSION}

Therefore, in the concluding remarks it is wished to state that passing an act is not sufficient. The need of hours is to implement and monitor the constitutional provision of the act properly. The 
consistent monitoring and intention of the political will is a must to make it successful. According to the UNESCO's education for all global monitoring report 2010, about 135 countries have constitutional provisions for free and non-discriminatory education for all. The much awaited right to education (RTE) Act which has been passed by the parliament of India should play an important role in achieving universal elementary education in India. The success and failure of RTE would largely depend on consistent political attention. Education which is free of cost up to a certain age must be accessible to all. The right to education is a fundamental right and UNESCO aims at education for all by 2015. Through education the child develops his emotional, intellectual and spiritual growth. Otherwise there cannot be a healthy growth of nation. India along with other countries of the world should also put sincere efforts to make this goal a real success.

\section{REFERENCES}

[1] Jha, Praveen and Pooja parvathi-Right to education Act: 2009, critical gaps and challenges-2010.

[2] A.P Avasthi-Indian constitution-2017.

[3] D.D Basu-Commentry and the constitution of India-2016.

[4] V. Krishna Ananth-The Indian Constitution and social Revolution-1900.

[5] R.V Badi- A text on Indian constitution-2014.

[6] M. Laxmikanth- Goverance in India-2014.

[7] D.D Basu- Introduction to the constitution India-2015.

[8] B.L Fadia-The constitution of India-2015.

[9] Govt. of India, Ministry of Human Resource Dept., Annual report-2006-07.

[10] Govt. of India, Education in Eleventh five year plan-2007-12.

Citation: Dr. S. Kumar Swami. "Analysis of the Right to Education in Indian Constitution" International Journal of Political Science (IJPS), vol 5, no.4, 2019, pp. 51-54. doi: http://dx.doi.org/10.20431/2454-9452.0504008.

Copyright: () 2019 Authors. This is an open-access article distributed under the terms of the Creative Commons Attribution License, which permits unrestricted use, distribution, and reproduction in any medium, provided the original author and source are credited. 